\title{
Pemantauan Fase Pertumbuhan Tanaman Padi Menggunakan Citra Radarsat-2 Quad Polarimetrik
}

\author{
Rian Nurtyawan , Gerryn Maulannisaa \\ Teknik Geodesi, Fakultas Teknik Sipil dan Perencanaan ITENAS, Bandung, Indonesia \\ Email: nurtyawan70@gmail.com
}

Received 30 Maret 2020| Revised 11 Agustus 2020| Accepted 13 Agustus 2020

\begin{abstract}
ABSTRAK
Indramayu merupakan salah satu lumbung padi Indonesia yang ada di wilayah Jawa Barat dimana Badan Pusat Statistik mencatat pada tahun 2014, Indramayu menghasilkan padi sebesar 1.361.374 ton. Untuk memantau produksi padi, sangat diperlukan pemantauan fase pertumbuhan tanaman padi, salah satu metodenya dengan teknologi penginderaan jauh sistem RADAR menggunakan citra RADARSAT-2 quad polarimetrik. Penelitian ini bertujuan untuk mengklasifikasi daerah fase pertumbuhan tanaman padi menggunakan metode Cloude Pottier H/A/ $\alpha$ (entropi/anisotropi/sudut alfa) dan mengevaluasi metode tersebut dalam klasifikasi fase pertumbuhan tanaman padi. Hasil dari penelitian ini yaitu peta klasifikasi fase pertumbuhan tanaman padi dimana dari keseluruhan akuisisi citra, luas lahan tertinggi adalah fase germination/laut yang berjumlah 2.368.242 m2 (22 September 2014). Hasil klasifikasi ini disesuaikan dengan bidang $H$ - $\alpha$ classification plane untuk mengetahui pada zona mana yang memiliki hamburan paling dominan. Hasil pada 18 Juni 2014 dan 5 Agustus 2014 menunjukkan zona 7 (fase panicle initiation/inisiasi malai), zona 8 (fase milk stage/gabah matang susu), dan zona 9 (fase germination/perkecambahan benih atau fase seeding/pertunasan) menjadi zona yang dominan dimana ketiga mekanisme memiliki arti double-bounce scattering (Z7), volume scattering (Z8), dan surface scattering (Z9) sedangkan pada 22 September 2014 dan 16 Oktober 2014 hamburan yang paling dominan terdapat pada Z8 (fase milk stage/gabah matang susu) dengan mekanisme volume scattering dan Z9 (fase germination/perkecambahan benih atau fase seeding/pertunasan) dengan mekanisme surface scattering.
\end{abstract}

Kata kunci: Pertumbuhan Padi, Klasifikasi, RADARSAT-2, H/A/ $\alpha$

\begin{abstract}
Indramayu is one of Indonesia's granary in West Java where Statistic Data Center noted that in 2014 Indramayu produced 1.361.374 tons of rice. It's necessary to monitor growth phase of rice plant for monitoring rice production, one of the method is remote sensing technology is the RADAR system with RADARSAT-2 image quad-polarimetric. This study aims to classify the phase of growth of rice plants using the Cloude Pottier H / A / a method (entropy / anisotropy / alpha angle) and evaluate these methods in classification of rice plant growth phases. The results of this study are the classification map of the rice plant phase where from the overall image acquisition, the highest land area is the germination / sea phase, which amounts to 2,368,242 $\mathrm{m}^{2}$ (22 September 2014). The classification results are adjusted with the $H-\alpha$ classification plane to find out which zone has the most dominant scattering. The result on 18 June 2014 and 5 August 2014 showed zone 7 (panicle initiation phase), zone 8 (milk stage phase), and zone 9 (germination/seeding) to be the dominant zone where the three mechanisms mean double-bounce scattering (Z7), volume scattering (Z8), and surface scattering (Z9) while on 22 September 2014 and 16 October 2014 the most dominant scattering is in Z8 (milk stage phase) with volume scattering mechanism and Z9 (germination/seeding phase) with surface scattering mechanism
\end{abstract}

Keywords: Rice Growth, Classification, RADARSAT-2, H/A/ . 


\section{PENDAHULUAN}

Kebutuhan paling mendasar bagi sumber daya manusia suatu bangsa adalah pangan [1]. Pangan di Indonesia mempunyai kedudukan yang sangat penting terutama makanan pokok karena menyangkut permasalahan politik, ekonomi, sosial dan budaya. Untuk menjaga ketersediaan beras di Indonesia, perlu ditingkatkan peran dari masyarakat dan pemerintah daerah guna menjaga ketersediaan beras di tingkat nasional. Salah satu cara untuk meningkatkan peran masyarakat guna menjaga ketersediaan beras pada tingkat daerah dan pedesaan adalah dengan tetap menanam padi dan meningkatkan hasil produksinya [2].

Menurut FAO [3] dalam Mosleh [4], Indonesia masuk dalam 7 negara dengan produksi beras terbesar di dunia, produksinya yaitu 66,4 juta ton. Jawa Barat merupakan provinsi dengan produksi padi terbesar ke-2 setelah Jawa Timur, ditunjukkan oleh data tahun 2014 yaitu 11.373.144 ton [5]. Salah satu lumbung padi Indonesia yang ada di wilayah Jawa Barat yaitu Indramayu. Produksi padi terkait dengan luas lahan padi. Meskipun luas lahan padi dan pertumbuhan padi bernilai besar, tetapi permintaan sering melebihi produksi [6]. Menurut data konsumsi rata-rata per kapita masyarakat Indonesia [7] pada tahun 2013 konsumsi beras masih berada pada urutan pertama dengan nilai 85.514 Kg. Oleh sebab itu informasi prediksi produksi padi berguna untuk mengetahui ketersediaan beras di Indonesia [8].

Dalam memantau produksi padi, sangat diperlukan pemantauan fase pertumbuhan tanaman padi. Salah satu metode yang efektif dalam memantau fase pertumbuhan tanaman padi adalah teknologi penginderaan jauh karena mengurangi keperluan biaya dan tenaga akibat survei lapangan. Dengan demikian, informasi pemantauan dari penginderaan jauh dapat membantu dalam pengembangan areal persawahan [8]. Menurut Konishi [9] disebutkan bahwa sensor-sensor optik hampir tidak mampu mendapatkan data yang diperlukan pada waktu yang tepat karena masalah tutupan awan selama masa pertumbuhan padi, oleh sebab itu SAR (Synthetic Aperture Radar) dapat menjadi alternatif untuk memantau fase pertumbuhan padi. Salah satu satelit pengindera SAR kanal C adalah RADARSAT-2 (RSAT-2) [10].

Sudah ada beberapa citra satelit SAR yang bisa diunduh secara gratis, namun tangal perekamannya sangat sulit untuk disesuaikan dengan fase pertumbuhan tanaman padi. Perekaman citra RSAT-2 disesuaikan dengan waktu survei lapangan. Peneliti meminta waktu khusus kepada pihak vendor untuk merekam sesuai dengan waktu yang diajukan (programming). Penelitian ini menggunakan citra RSAT-2 quad polarimaterik ( $\mathrm{HH}, \mathrm{HV}, \mathrm{VH}$ dan VV) untuk memetakan fase pertumbuhan padi di Indramayu. Akuisisi citra RSAT-2 yang digunakan mewakili keseluruhan fase pertumbuhan tanaman yaitu Bulan Juni, Agustus, September, dan Oktober 2014. Metode dekomposisi polarimetrik H/A/ $\alpha$ dari S.R. Cloude dan E. Pottier digunakan untuk mengetahui perbedaan mekanisme hamburan dan sifat fisik tanaman padi.

\section{METODOLOGI}

\subsection{Data, Peralatan, dan Lokasi Penelitian}

Data yang digunakan adalah citra Radarsat-2 dengan polarisasi penuh diperoleh secara berulang selama musim tanam pada tahun 2014 seperti yang ditunjukan pada Tabel 1. Analisis klasifikasi dilakukan pada 18 Juni 2014 ketika akusisi data Rsat-2 berada di awal fase pertumbuhan tanam.

Pengolahan citra Rsat-2 menggunakan perangkat lunak open source PolSAR Pro versi 4.2 ASF MapReady versi 3.1, sedangkan untuk proses layout menggunakan perangkat lunak ArcGIS 10.3 seperti ditunjukan pada Tabel 2.

Daerah penelitian terletak di Kabupaten Indramayu $\left(107^{\circ} 52^{\prime}-108^{\circ} 36^{\prime} \mathrm{BT}\right.$ dan garis lintang $6^{\circ} 15^{\prime}-$ $6^{\circ} 40^{\prime}$ ) seperti ditunjukan pada Gambar 1. Eksperimen lapangan dilakukan di lokasi padi di Indramayu. Lokasi Kabupaten Indramayu yang membentang di sepanjang pantai utara Pulau Jawa. 
Wilayah ketinggian umumnya berkisar antara 0-18 $\mathrm{m}$ di atas permukaan laut dan daerah dataran rendah berkisar antara 0-6 $\mathrm{m}$ di atas permukaan laut yang terdiri dari rawa, kolam, sawah. Rata-rata suhu udara harian cukup tinggi $28^{\circ}$ Celcius. Situasi ini rentan terhadap drainase, ketika curah hujan tinggi daerah rendah akan terjadi genangan air dan ketika musim kemarau akan menyebabkan kekeringan.

Tabel 1. Data Penelitian

\begin{tabular}{|c|c|c|c|}
\hline No & Data & Sumber & Spesifikasi \\
\hline 1. & RADARSAT-2 & $\begin{array}{l}\text { MacDonnald } \\
\text { Detwiller and } \\
\text { Associates- Canada }\end{array}$ & $\begin{array}{l}\text { - Akuisisi citra 18 Juni 2014, } 5 \\
\text { Agustus 2014, } 22 \text { September } \\
\text { 2014, dan 16 Oktober } 2014 \\
\text { - Resolusi } 8 \text { m x } 8 \text { m } \\
\text { - Polarisasi HH, VV, VH dan } \\
\text { HV }\end{array}$ \\
\hline 2. & $\begin{array}{l}\text { Foto Survei Lapangan } \\
\text { Fase Pertumbuhan } \\
\text { Tanaman Padi }\end{array}$ & Nurtyawan dkk., 2017 & $\begin{array}{l}\text { - } 18 \text { Juni } 2014 \\
\text { - } 5 \text { Agustus } 2014 \\
\text { - } 22 \text { September } 2014 \\
\text { - } 16 \text { Oktober } 2014\end{array}$ \\
\hline
\end{tabular}

Tabel 2. Peralatan Penelitian

\begin{tabular}{cll}
\hline No. & \multicolumn{1}{c}{ Perangkat Lunak } & \multicolumn{1}{c}{ Kegunaan } \\
\hline 1. & PolSAR Pro versi 4.2 & Proses pengolahan Data Rsat-2 \\
2. & ASF MapReady versi 3.1 & Koreksi Geometrik \\
3. & ArcGIS versi 10.3 & Layouting \\
\hline
\end{tabular}

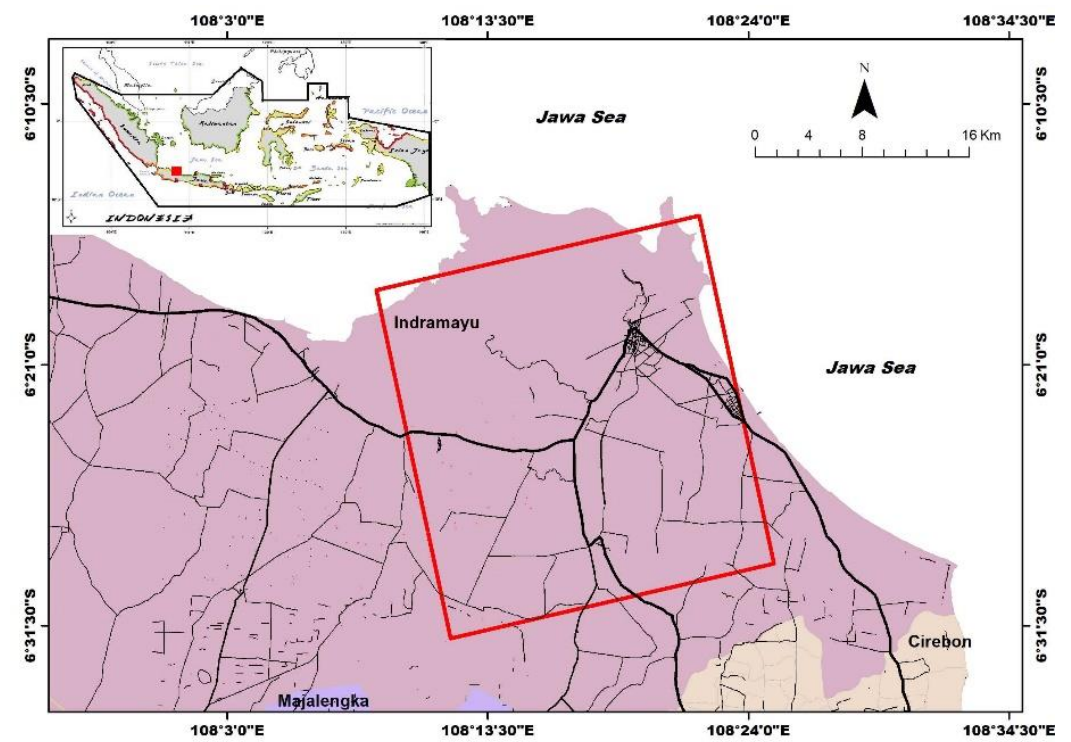

Gambar 1. Wilayah studi Indramayu, Jawa Barat ditunjukkan oleh poligon warna merah sesuai dengan area satu scene akuisisi Radarsat-2

\subsection{Metodologi Penelitian}

Metode $\mathrm{H} / \mathrm{A} / \alpha$ mengklasifikasikan data polarimetrik RADAR berdasarkan dekomposisi eigenvalue atas matrik koherensi atau kovariansi menjadi parameter entropi $(H)$, sudut alfa $(\alpha)$ dan anistropi (A) dimana parameter tersebut diperoleh dari rumus [11]. Data RSAT-2 diolah melalui proses ekstraksi menjadi matriks Siclair/Scattering (S) dan matriks koherensi (T). Tahap selanjutnya yang masih termasuk pre-processing yaitu speckle filtering dan koreksi geometrik. Klasifikasi dilakukan dengan membagi sesuai interpretasi $\mathrm{H}-\alpha$ classification plane yang kemudian divalidasi dengan survei lapangan 
yang dilakukan pada penelitian [12]. Kelas terdiri atas kelas germination/laut, seeding, tillering, stem elongation, panicle initiation, heading, flowering, dan panen. Alur proses pengolahan data penelitian seperti ditunjukan pada Gambar 2.

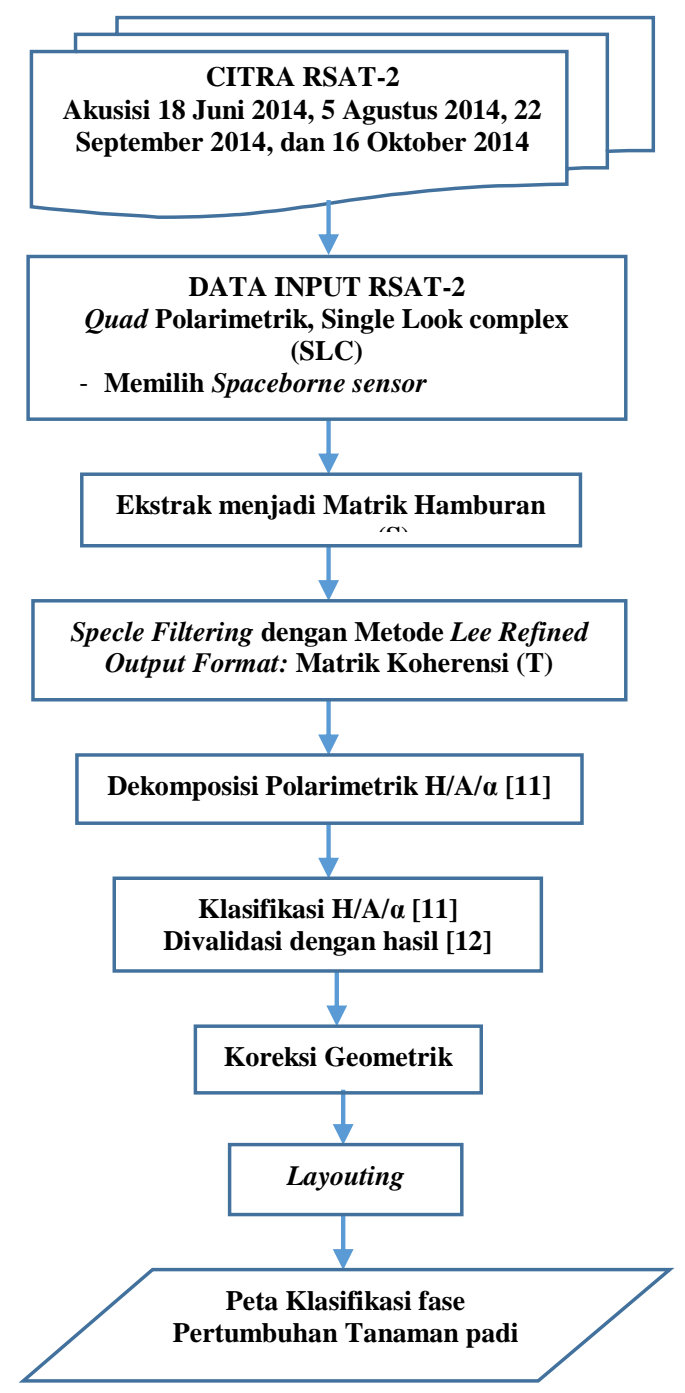

Gambar 2. Metodologi Penelitian

\section{Ektstrak Menjadi Matriks S dan Matriks T}

Proses ini dilakukan pada software PolSAR Pro versi 6.0. Konsep dasar hamburan dalam data polarimetrik dibentuk oleh matriks $S$ dimensi 2x2 yang dapat dilihat pada Persamaan (1). Matriks $S$ digambarkan dalam bentuk vektor berdasaran basis Pauli dengan formulasi vektorial pada Persamaan (2). 
Pemantauan Fase Pertumbuhan Tanaman Padi Menggunakan Citra Radarsat-2 Quad Polarimetrik

$$
\begin{aligned}
& S=\left(\begin{array}{ll}
S_{h h} & S_{h V} \\
S_{W h} & S_{W V}
\end{array}\right) \\
& \overrightarrow{k_{a p}}=\frac{1}{\sqrt{2}}\left(S_{h h}+S_{W V} \quad S_{h h}-S_{V D} \quad 2 S_{V D}\right)^{T}
\end{aligned}
$$

Keterangan:

$\mathrm{h}$ dan $\mathrm{v}=$ Gelombang horizontal dan vertikal

$\mathrm{S} \quad=$ Hamburan

$\underline{S_{\mathrm{hv}}} \quad=$ Hamburan (pancaran: gelombang vertikal dan penerimaan: gelombang horizontal)

$\overrightarrow{k 3 p} \quad=$ Matriks $\mathrm{S}$ dalam formulasi vektorial

$\mathrm{T} \quad=$ Transpos

$\overrightarrow{k 3 p}$ penting untuk membangun matriks koherensi $(\mathrm{T})$ yang digunakan untuk mendapatkan parameter $\mathrm{H}$ dan $\alpha$. Matriks koherensi (T) dihitung berdasarkan basis Pauli yang ditunjukkan dalam Persamaan (3).

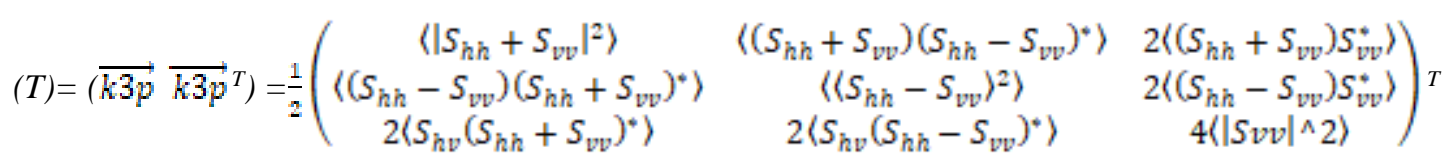

\section{Speckle Filtering}

Informasi yang diperoleh dari Syntetic Aperture Radar (SAR) masih memiliki kelemahan, diantaranya adanya noise atau speckle pada citra radar yang dapat mengganggu dalam ekstraksi informasi [13]. Penelitian ini menggunakan speckle filtering metode Lee Refined dengan ukuran window (5 x 5). Didalam penelitian ini, metode Lee Refined yang digunakan karena mempertahankan batas yang jelas dari permukaan tanah menurut penelitian yang dilakukan oleh Ma [14] dan Hajensek [15], metode Lee Refined dapat menyaring area yang homogen dan dapat mempertahankan bagian tepi dan tekstur dari area yang dimaksud, sehingga cocok untuk membedakan objek padi dan non-padi serta untuk mengelompokkan padi berdasarkan fase pertumbuhannya [16].

\section{Dekomposisi Polarimetrik H/A/ $\alpha$}

Proses dekomposisi menggunakan metode $\mathrm{H} / \mathrm{A} / \alpha$ [11]. Analisis eigenvector dari matriks koherensi (T) dilakukan untuk mendapatkan parameter dekomposisi. Parameter dekomposisi tersebut yaitu $\mathrm{H}$ (entropi) yang menunjukkan keacakan hamburan, $\alpha$ (sudut alfa) mengindikasikan hamburan yang dominan, dan A (anisotropi) yang menunjukkan kekuatan relatif yang sesuai dari eigenvector kedua dan ketiga [12].

\section{Klasifikasi $\mathrm{H} / \mathrm{A} / \alpha$}

Proses selanjutnya adalah klasifikasi fase pertumbuhan tanaman padi dengan menggunakan klasifikasi $\mathrm{H} / \mathrm{A} / \alpha$. Tool yang digunakan yaitu $\mathrm{H} / \mathrm{A} / \alpha$ classification pada menu polarimetric segmentation. Klasifikasi ini termasuk klasifikasi unsupervised. Hasil proses ini adalah klasifikasi fase pertumbuhan tanaman padi dan $\mathrm{H}-\alpha$ classification plane dari klasifikasi. Kelas yang digunakan pada klasifikasi fase pertumbuhan tanaman padi mengacu pada hasil interpretasi yang dilakukan pada 9 zona $\mathrm{H}-\alpha$ classification plane yang ditunjukkan pada Tabel 3. Selanjutnya kelas klasifikasi divalidasi dengan mengacu pada survei lapangan yang telah dilakukan oleh Putra [13]. Ada beberapa fase yang mengalami pemisahan dan penggabungan kelas seperti pemisahan fase seeding/germination menjadi kelas seeding dan kelas germination/laut serta penggabungan fase milk stage, dough stage, dan mature stage menjadi kelas panen. 
Gerryn Maulannisaa dan Rian Nurtyawan

Tabel 3. Interpretasi H- Classification Plane

\begin{tabular}{|c|c|c|c|c|c|c|}
\hline Zona & Entropy & Alpha & $\begin{array}{c}\text { Tipe } \\
\text { Scattering } \\
\end{array}$ & Fase & Tahap/Sub-Fase & Gambar \\
\hline 1 & $0,9-1$ & $55-90$ & $\begin{array}{l}\text { Entropy tinggi } \\
\text { double-bounce } \\
\text { scattering }\end{array}$ & Reproduktif & $\begin{array}{l}\text { Flowering/ } \\
\text { Berbunga }\end{array}$ & \\
\hline 2 & $0,9-1$ & $40-45$ & $\begin{array}{l}\text { Entropy tinggi } \\
\text { volume } \\
\text { scattering }\end{array}$ & Panen & $\begin{array}{l}\text { Mature Stagel } \\
\text { Gabah Matang } \\
\text { Penuh }\end{array}$ & \\
\hline 3 & $0,9-1$ & $0-45$ & $\begin{array}{l}\text { Entropy tinggi } \\
\text { surface } \\
\text { scattering }\end{array}$ & Vegetatif & $\begin{array}{l}\text { Stem Elongation / } \\
\text { Pemanjangan } \\
\text { Batang }\end{array}$ & \\
\hline 4 & $0,5-0,9$ & $50-90$ & $\begin{array}{l}\text { Entropy } \\
\text { menengah } \\
\text { double-bounce } \\
\text { scattering }\end{array}$ & Reproduktif & $\begin{array}{l}\text { Heading/Keluar } \\
\text { Malai }\end{array}$ & \\
\hline 5 & $0,5-0,9$ & $40-50$ & $\begin{array}{l}\text { Entropy } \\
\text { menengah } \\
\text { volume } \\
\text { scattering }\end{array}$ & Panen & $\begin{array}{l}\text { Dough Stagel } \\
\text { Gabah Setengah } \\
\text { Matang }\end{array}$ & \\
\hline 6 & $0,5-0,9$ & $0-40$ & $\begin{array}{l}\text { Entropy } \\
\text { menengah } \\
\text { surface } \\
\text { scattering }\end{array}$ & Vegetatif & $\begin{array}{l}\text { Tillering/ } \\
\text { Pembentukan } \\
\text { Anakan }\end{array}$ & \\
\hline 7 & $0-0,5$ & $\begin{array}{l}47,5- \\
90\end{array}$ & $\begin{array}{l}\text { Entropy } \\
\text { rendah } \\
\text { double-bounce } \\
\text { scattering }\end{array}$ & Reproduktif & $\begin{array}{l}\text { Panicle } \\
\text { Initiation/Inisiasi } \\
\text { Malai }\end{array}$ & \\
\hline 8 & $0-0,5$ & $\begin{array}{l}42,5- \\
47,5\end{array}$ & $\begin{array}{l}\text { Entropy } \\
\text { rendah volume } \\
\text { scattering }\end{array}$ & Panen & $\begin{array}{l}\text { Milk Stagel } \\
\text { Gabah Matang } \\
\text { Susu }\end{array}$ & \\
\hline
\end{tabular}

\section{Koreksi Geometrik}

Proses ini dilakukan pada software ASF MapReady versi 3.1 yang telah disambungkan dengan software PolSAR Pro versi 4.2. Koreksi geometrik ini sangat penting pada tahap pra-processing data SAR. Citra satelit SAR yang standar pada dasarnya masih mengandung berbagai distorsi/kesalahan yang diakibatkan oleh sistem pengakuisisian data dengan arah menyamping (side looking imaging geometry) [17]. Koreksi geometrik dilakukan untuk merubah sistem slant range menjadi koordinat sistem ground range [18].

\section{HASIL DAN PEMBAHASAN}

Hasil yang diperoleh dari pelaksanaan penelitian pemantauan fase pertumbuhan tanaman padi menggunakan metode $\mathrm{H} / \mathrm{A} / \alpha$ (entropi/anisotropi/alfa) [11] adalah dekomposisi parameter $\mathrm{H} / \mathrm{A} / \alpha$ (entropi/anisotropi/alfa) seperti ditunjukan pada Gambar 3(a), 3(b), 3(c). 


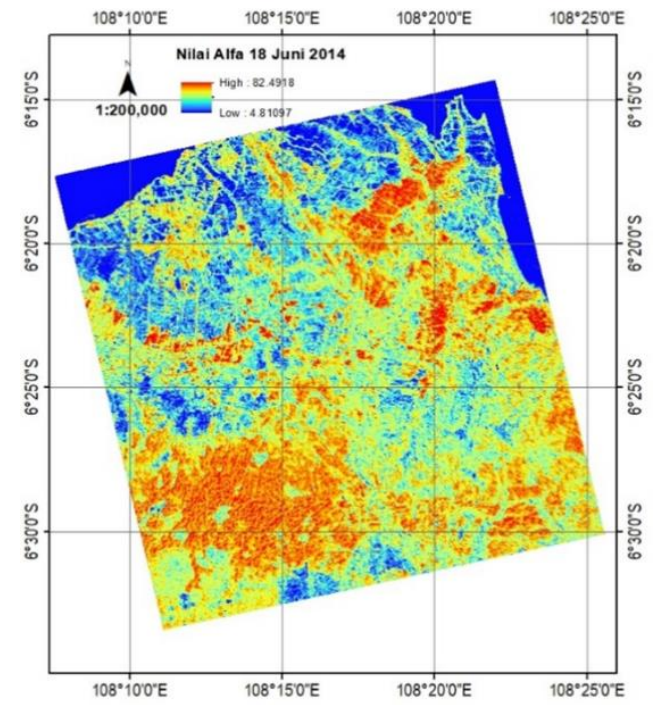

(a)

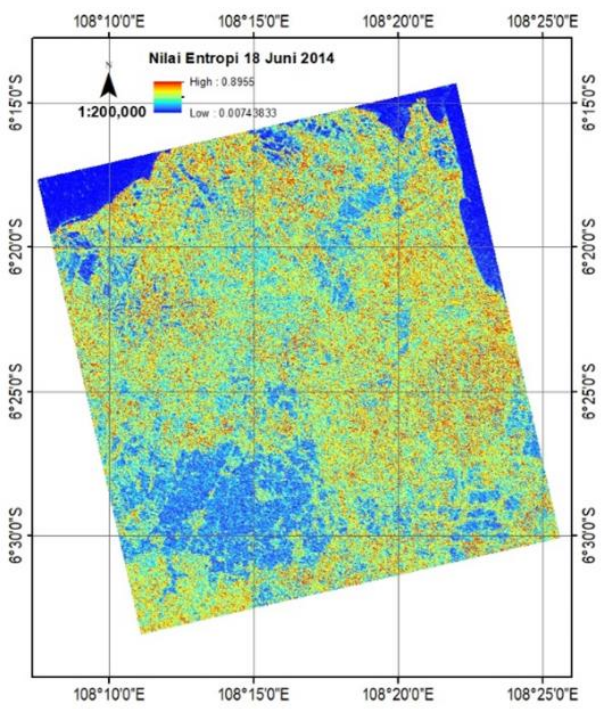

(b)

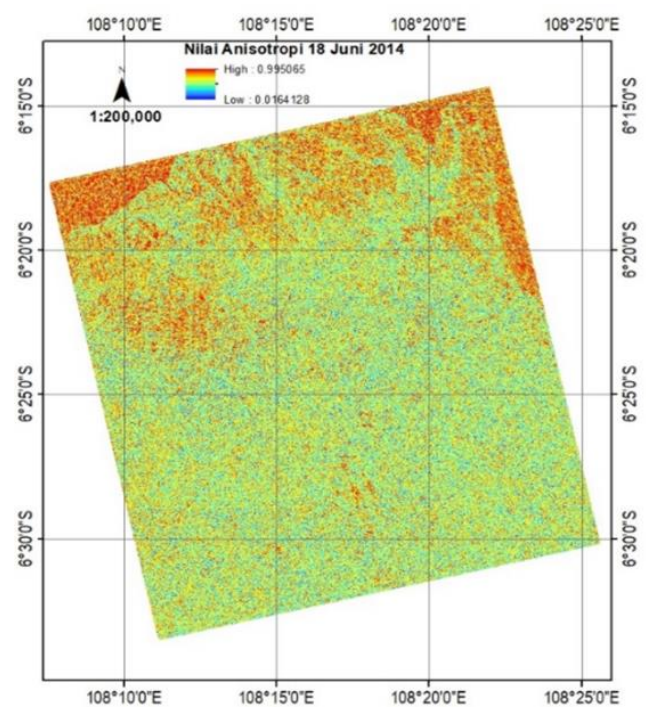

(c)

Gambar 3. Hasil Dekomposisi Parameter H/A/a 18 Juni 2014: (a) Alfa, (b) Anisotropi, (c) Entropi

Berikut nilai parameter dari dekomposisi polarimetrik Cloude Pottier seperti ditunjukan pada Tabel 4.

Tabel 4. Nilai Parameter Dekomposisi Cloude Pottier

\begin{tabular}{lrrr}
\hline $\begin{array}{c}\text { Tanggal } \\
\text { Akusisi Data }\end{array}$ & Entropi (H) & \multicolumn{1}{c}{ Alfa (a) $\left(^{\circ}\right)$} & Anisotropi (A) \\
\hline 18 Jun 2014 & $0,0074-0,8955$ & $4,8917-82,4918$ & $0,0164128-0,995065$ \\
5 Agu 2014 & $0,00301397-0,885234$ & $7,48948-84,8452$ & $0,0204628-0,994804$ \\
22 Sep 2014 & $0,00474438-0,876099$ & $2,99335-81,9436$ & $0,0223985-0,994094$ \\
16 Okt 2014 & $0,00474241-0,852708$ & $4,35724-74,802$ & $0,0269079-0,994568$ \\
\hline
\end{tabular}

Setiap parameter menyediakan informasi yang relevan mengenai hamburan, tetapi jika parameter itu berdiri sendiri tidak cukup untuk sepenuhnya menafsirkan respon apa yang terjadi [19]. Parameter alfa (nilai berkisar antara $0^{\circ}-90^{\circ}$ ) seperti yang ditunjukan pada Gambar 3a menunjukkan warna merah yang mengindikasikan surface scattering (nilai alfa $0^{\circ}$ ) dan semakin meningkat nilai alfanya maka 
warna yang ditunjukkan semakin merah yang artinya mekanisme hamburannya juga akan berubah menjadi double-bounce scattering (nilai alfa $45^{\circ}$ ) atau volume scattering (nilai alfa $90^{\circ}$ ). Hal ini sesuai dengan Cloude [11] yang mengatakan besarnya nilai alfa menunjukan mekanisme hamburan yang paling dominan.

Mekanisme hamburan yang ditunjukkan oleh nilai alfa membuktikan bahwa parameter alfa dapat menjadi parameter yang mendukung untuk mengetahui fase pertumbuhan tanaman padi dimana surface scattering dapat diartikan sebagai lahan yang memiliki permukaan air/lumpur (belum ditumbuhi tanaman padi) atau dapat diartikan tanaman padi yang baru bertambah panjang dan bertambah jumlah daunnya seperti fase vegetatif (germination, seeding, tillering, dan stem elongation); double-bounce scattering dapat diartikan lahan dengan tanaman padi yang bertambah jumlah malai padi serta mulai siap bereproduksi seperti fase reproduktif (panicle initation, heading, dan flowering) dimana ukuran dan struktur malai merupakan faktor penting yang berkontribusi terhadap hasil dan kualitas padi Mo [20] dalam Rahayu [21]; dan volume scattering dapat diartikan dengan tanaman padi yang mengalami pematangan serta memiliki jumlah daun dan malai yang banyak sehingga mekanisme hamburan ini terjadi pada kanopi tanaman padi seperti fase panen (milk stage, dough stage, dan mature stage).

Menurut Pramono [22], meskipun sudut alfa ditemukan berguna untuk menjelaskan jenis hamburan, parameter ini tampaknya kurang memberikan kontribusi yang signifikan terhadap interpretasi data. Perlu parameter lain untuk mengetahui fase pertumbuhan tanaman padi. Nilai entropi seperti yang ditunjukan pada Gambar 3c menunjukkan tingkat keacakan hamburan dimana nilainya berkisar antara 0 sampai 1. Nilai entropi 0 mengindikasikan lahan sawah yang berair/lumpur (fase germination dan fase seeding). Semakin tinggi nilai entropi maka daerah tersebut semakin bervegetasi, dapat dikatakan tanaman padi yang semakin bervegetasi adalah tanaman yang bertambah tinggi maupun jumlah daunnya serta semakin matang bulir padinya. Menurut penelitian yang dilakukan Pramono [22] entropi lebih banyak berperan dalam klasifikasi umur tanaman padi dibandingkan anisotropi dan sudut alfa. Parameter ketiga yaitu parameter anisotropi seperti yang ditunjukan pada Gambar 3c yang memberikan informasi tambahan mengenai banyaknya komponen hamburan. Nilai Anisotropi seperti yang ditunjukan pada Gambar 3b berkisar antara 0-1 dimana nilai yang mendekati 0 menunjukkan azhimutal symmetry surface dan nilai $\mathrm{A}>0$ mengindikasikan peningkatan jumlah anisotropic scattering-nya [13]. Dikatakan sebelumnya bahwa anisotropi merupakan informasi tambahan sehingga anisotropi berkaitan dengan entropi karena jika entropi memiliki nilai sedang maka ada lebih sari satu mekanisme hamburan tunggal yang berkontribusi pada sinyal hamburan balik dan anisotropi yang tinggi akan menunjukkan mekanisme hamburan kedua lebih penting, sedangkan jika nilai anisotropi rendah maka ada kontribusi yang sangat penting dari mekanisme hamburan ketiga [19].

Hasil tersebut mengungkapkan efisiensi algoritma ini pada perbedaan berdasarkan karakteristik hamburan. Informasi tekait pada setiap zona dapat digunakan untuk identifikasi tipe lahan [23]. Dapat dilihat pada Gambar 3 bahwa dalam 1 scene citra Rsat-2 memiliki keanekaragaman umur tanaman padi. Hasil klasifikasi menggunakan ketiga parameter ini menunjukkan metode Cloude Pottier dapat digunakan untuk klasifikasi fase pertumbuhan tanaman padi. Hal ini didukung penelitian sebelumnya yang menggunakan metode Cloude Pottier untuk klasifikasi fase pertumbuhan tanaman padi dan mengetahui umur tanaman padi, seperti yang dilakukan oleh Imai [24].

Penggunaan C-band pada penelitian ini berpengaruh pada hamburan yang didapatkan oleh sensor. Penggunaan C-band pada Rsat-2 mempengaruhi backscattering dari objek tanaman padi karena sinyal yang dikirimkan oleh C-band dapat mencapai hingga kanopi objek tanaman padi. Lain halnya dengan L-band yang pengiriman sinyalnya bisa mencapai permukaan tanah dimana objek padi ditanami. Penggunaan C-band dalam pemantauan fase pertumbuhan tanaman padi telah sesuai karena penelitian ini terfokus pada objek tanaman padi, akan tetapi jika menggunakan L-band dalam pemantauan fase pertumbuhan tanaman padi dinilai kurang berpengaruh karena sinyal yang dikirimkan bisa mencapai permukaan tanah dan hal tersebut kurang sesuai dengan objek yang menjadi fokus pada penelitian ini. 
Pemantauan Fase Pertumbuhan Tanaman Padi Menggunakan Citra Radarsat-2 Quad Polarimetrik

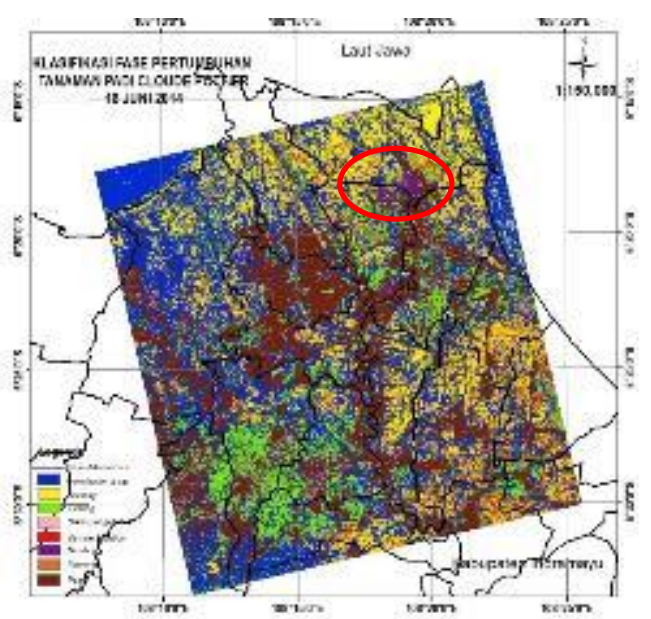

Gambar 4. Hasil Klasifikasi Fase Pertumbuhan Tanaman Padi 18 Juni 2014

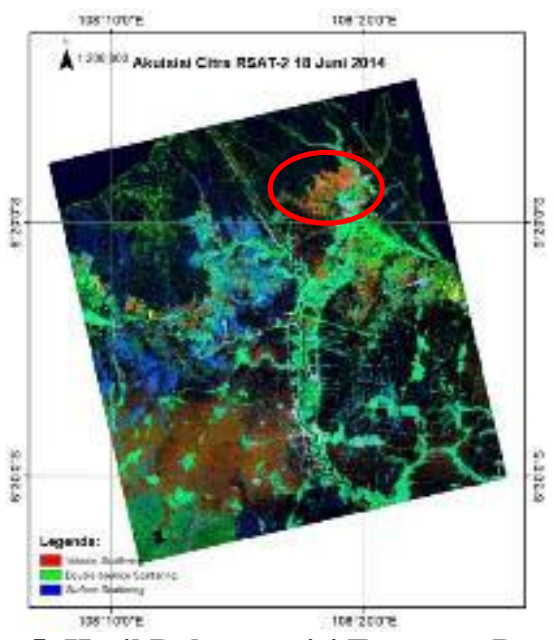

Gambar 5. Hasil Dekomposisi Freeman-Durden 18 Juni 2014

(Sumber:[12])

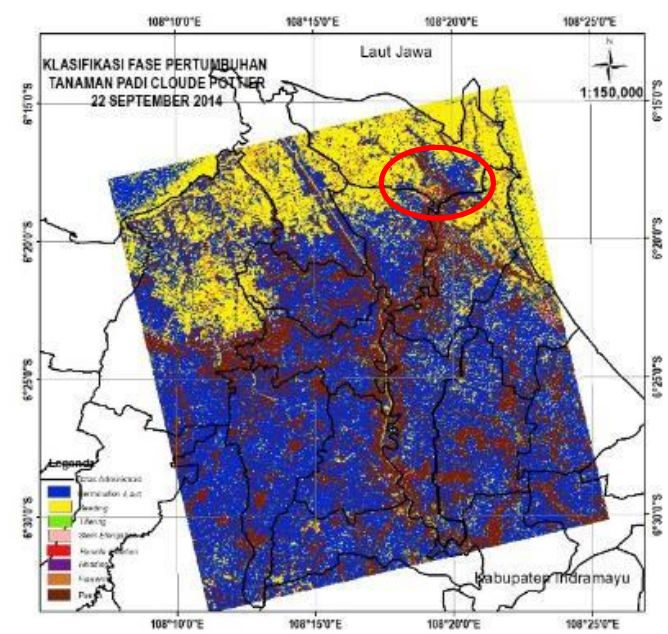

Gambar 8. Hasil Klasifikasi Fase Pertumbuhan Tanaman Padi 22 September 2014

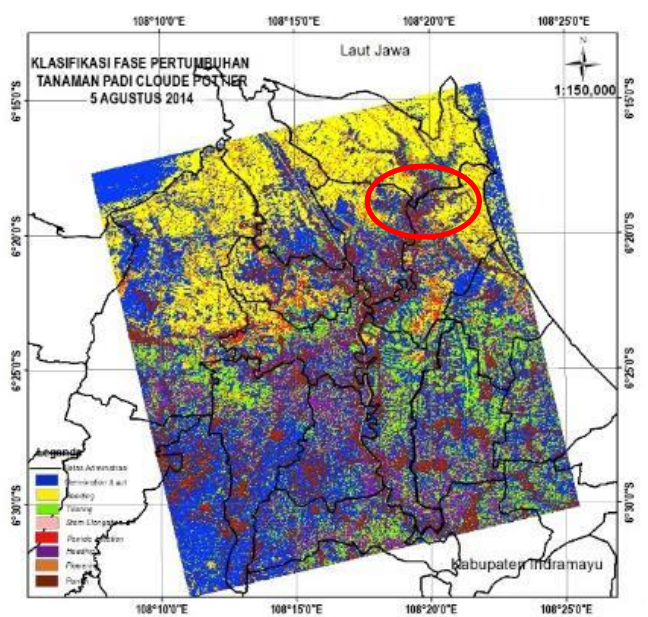

Gambar 6. Hasil Klasifikasi FasePertumbuhan Tanaman Padi 5 Agustus 2014

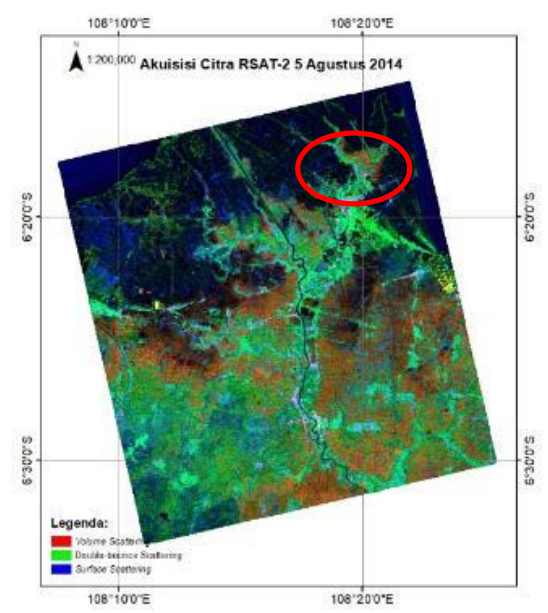

Gambar 7. Hasil Dekomposisis Freeman-Durden 5 Agustus 2014 (Sumber:[12])

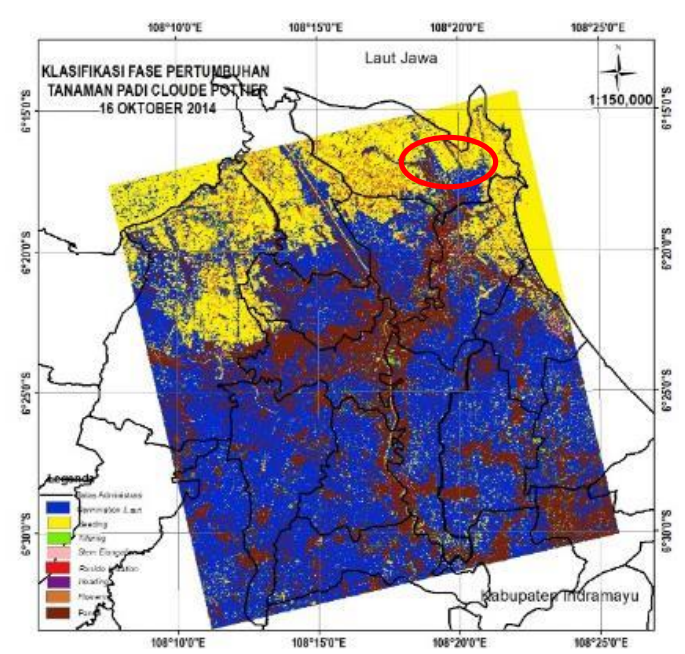

Gambar 10. Hasil Klasifikasi FasePertumbuhan Tanaman Padi 16 Oktober 2014 


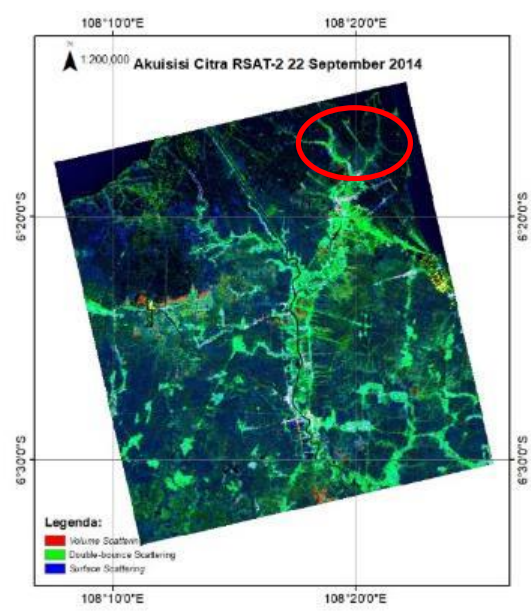

Gambar 9 Hasil Dekomposisi Freeman-Durden 22 September 2014

(Sumber:[12])

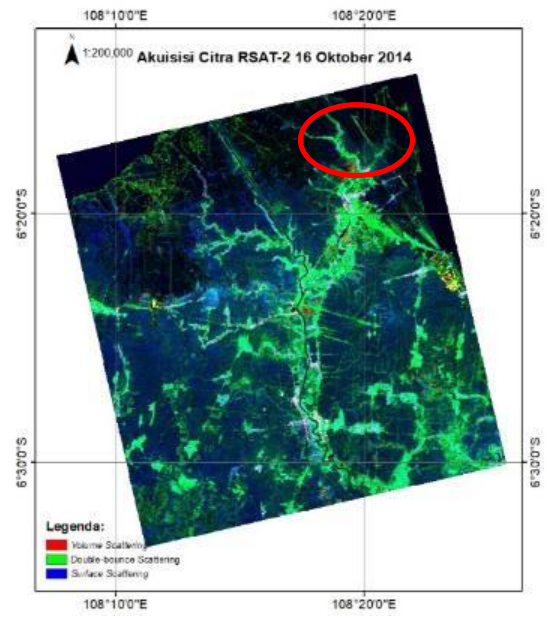

Gambar 11 Hasil Dekomposisi Freeman-Durden 16 Oktober 2014

(Sumber:[12])

Lingkaran merah pada Gambar 4 menunjukkan fase yang dihasilkan dari klasifikasi H/A/ $\alpha$ (entropi/anisotropi/alfa) adalah heading (keluar malai) ditunjukkan dengan warna ungu, hal itu didukung oleh hasil dari acuan seperti yang ditunjukan dalam Gambar 5 yang menunjukkan doublebounce scattering (ditunjukkan oleh warna kemerahan) artinya tanaman padi memiliki jumlah daun yang bertambah dan menyebabkan adanya mekanisme double-bounce scattering. Di lokasi yang sama pada Gambar 6 menunjukkan terjadinya fase seeding (warna kuning) yang didukung oleh Gambar 7 dimana ditunjukkan adanya mekanisme surface scattering (ditunjukkan oleh warna kebiruan) yang mengindikasikan belum adanya tanaman padi atau belum terlihatnya bagian-bagian tanaman padi secara jelas. Kemudian pada Gambar 8 di lokasi yang sama terlihat fase seeding (warna kuning) dan fase panicle initiation (warna merah) dimana pada Gambar 9 menunjukkan surface scattering (ditunjukkan oleh warna kebiruan) dan sedikit kemerahan yang menunjukkan mekanisme doublebounce scattering. Di lokasi yang sama di Gambar 10 terlihat fase seeding (warna kuning), fase tillering (warna kehijauan), dan fase heading (warna ungu). Hal tersebut didukung oleh Gambar 11 yang menunjukkan surface scattering (ditunjukkan oleh warna kebiruan) mengindikasikan belum adanya tanaman padi atau belum terlihatnya bagian tanaman padi dengan jelas dan double-bounce scattering (ditunjukkan oleh warna kemerahan) yang mengindikasikan tanaman padi muda yang belum memiliki jumlah daun yang banyak.

Klasifikasi dan dekomposisi polarimetrik yang digunakan pada penelitian ini mengacu pada hasil Nurtyawan [12] dimana pada penelitian tersebut digunakan metode Freeman-Durden. Hasil dekomposisi polarimetrik Cloude Pottier yang digunakan pada penelitian ini menggunakan tiga parameter (entropi, anisotropi, dan alfa) atau disimbolkan $(\mathrm{H} / \mathrm{A} / \alpha)$ untuk menentukan fase pertumbuhan tanaman padi, sedangkan metode Freeman-Durden menggunakan tiga komponen mekanisme hamburan dalam menenetukan fase pertumbuhan tanaman padi sehingga klasifikasi yang dihasilkan dari kedua metode tersebut terdapat perbedaan fase pertumbuhan tanaman padi pada beberapa bagian. Berikut adalah hasil $\mathrm{H}-\alpha$ classification plane. 


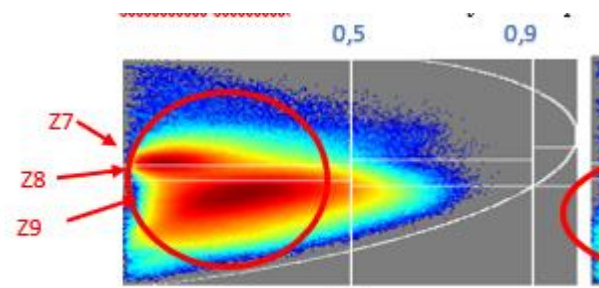

(a)

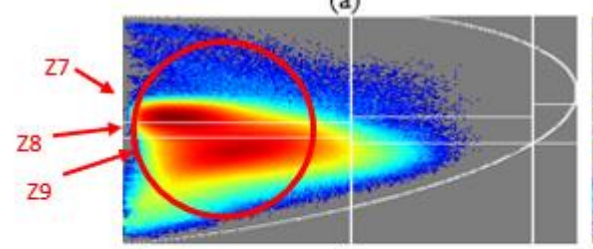

(b)

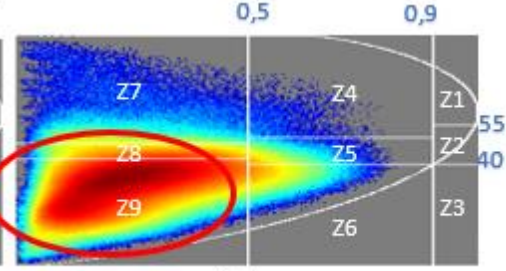

(c)

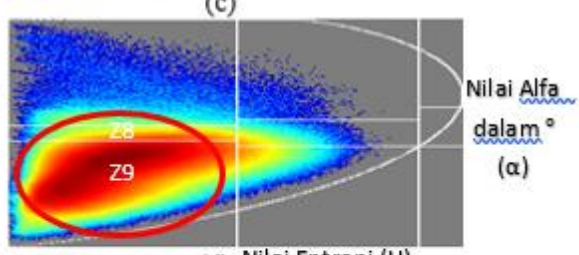

(d) Nilai Entropi (H)

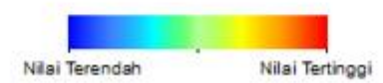

Gambar 12 H-a Classification Plane: (a) 18 Juni 2014 (b) 5 Agustus 2014 (c) 22 September 2014 (d) 16 Oktober 2014

Menurut Hajensek[15] hasil klasifikasi yang didapatkan perlu penyesuaian dengan bidang $\mathrm{H}-\alpha$ classification plane untuk mengetahui pada zona mana yang memiliki hamburan paling dominan. Gambar 11 (a) dengan nilai tertinggi (paling dominan) yang ditunjukkan oleh warna merah tua berada Z7 (panicle initiation) dan Z9 (seeding/germination).

Hasil pada Gambar 12(b) (5 Agustus 2014) menunjukkan pengurangan pada Z9 (seeding/germination) dan nilai yang paling tinggi/ paling dominan hanya berada pada Z7 (panicle initiation). Hal ini dikarenakan adanya pengurangan luas fase seeding/germination pada Z9. Walaupun pada kedua akuisisi menunjukkan adanya warna merah pada Z8 tetapi Z8 bukanlah nilai tertinggi dari semua zona karena tidak terdapat warna merah tua pada zona tersebut. Setelah 48 hari (22 September 2014) dapat dilihat nilai paling tinggi berada pada Z9 (seeding/germination) yang ditunjukkan oleh warna merah tua pada Gambar 12 (c). Hal ini diartikan bahwa ada peningkatan luas fase seeding/germination dan pengurangan luas fase panicle initiation (Z7) pada hasil klasifikasi. Gambar 12 (d) juga menunjukkan nilai tertinggi berada pada Z9 (seeding/germination).

Hal ini serupa dengan hasil pada akuisisi sebelumnya (22 September 2014), hanya saja memiliki peningkatan karena warna merah pada zona ini lebih tua daripada akuisisi sebelumnya. Hal ini didukung oleh penelitian yang dilakukan oleh Pramono [22] dimana zona 7 termasuk zona low entropy multiple scattering (double-bounce scattering) yaitu zona yang mencirikan cukup besarnya pengaruh hamburan balik double bounce karena tinggi dari tanaman padi masih rendah, zona 8 menunjukkan low dipole scattering yang mengindikasikan wilayah dengan vegetasi rendah dan baru menunjukkan adanya bulir/gabah baru, dan zona 9 merupakan zona low entropy surface scattering yang mengindikasikan wilayah cenderung terbuka atau mengalami tahap seeding/germination/laut dimana pada tahap tersebut baru mengalami perkecambahan benih atau pertunasan sehingga belum jelas terlihat bagian-bagian dari tanaman padi. 


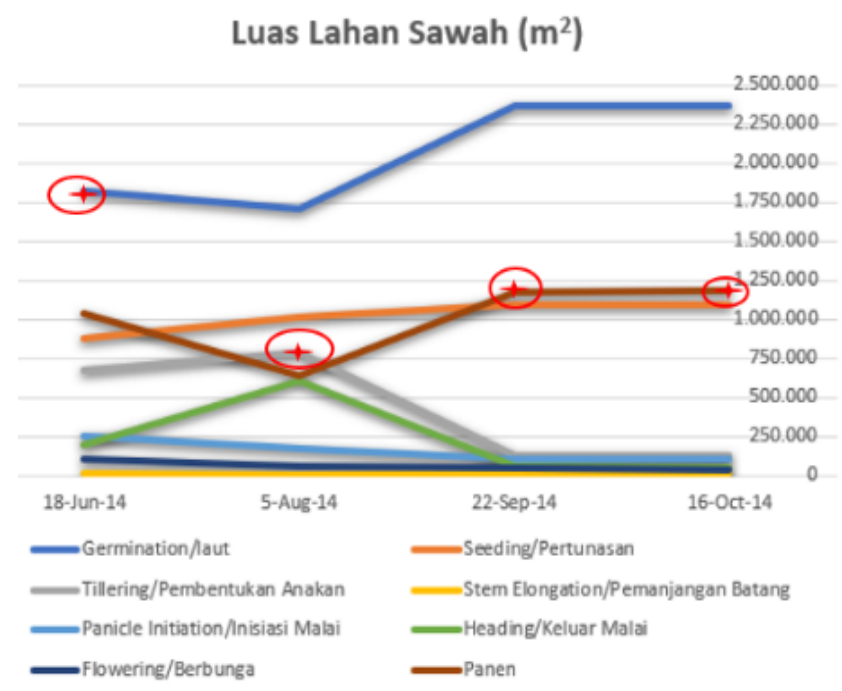

Gambar 13. Grafik Luas Lahan Sawah

Tabel 5. Fase Pertumbuhan Padi Berdasarkan Jarak Antar Akuisisi Citra dan Toan dkk. (1997)

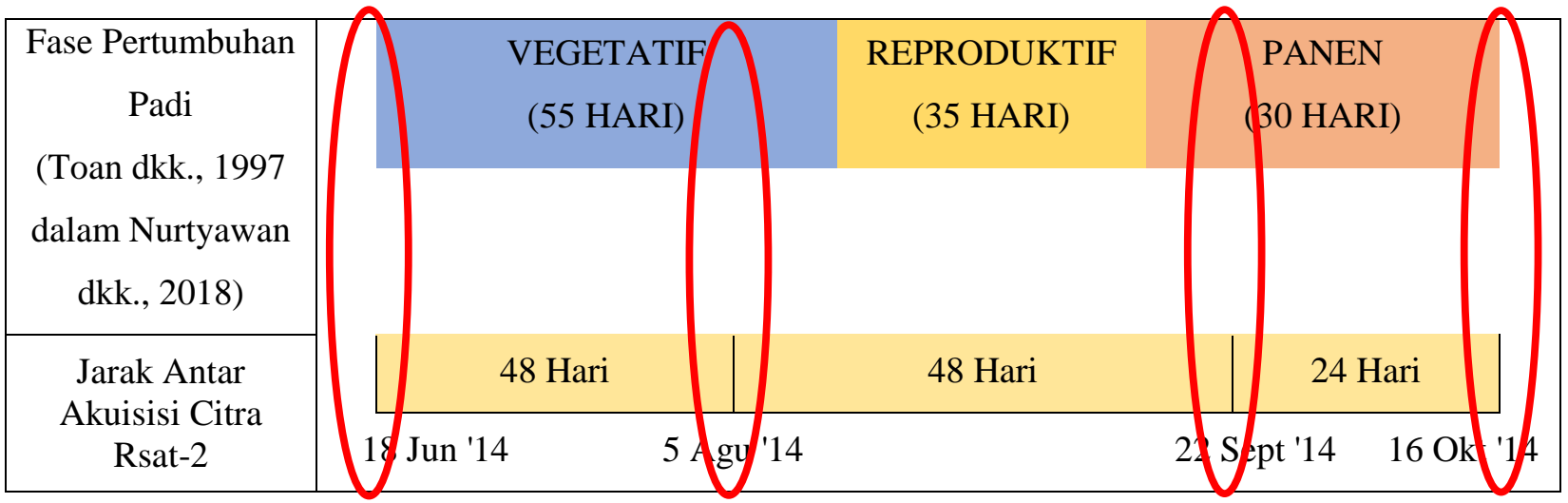

Penanaman padi di wilayah Indramayu menunjukkan ketidakseragaman waktu awal penanaman tanaman padi (heterogen). Hal ini mengakibatkan adanya luas lahan sawah dengan fase pertumbuhan tanaman padi yang berbeda-beda pada awal mula pemantauan tanaman padi (18 Juni 2014). Dalam mempermudah analisis kesesuaian klasifikasi maka analisis mengenai luas lahan sawah difokuskan pada 1 keadaan dimana 18 Juni 2014 mengalami fase germination/laut sesuai dengan kalender tanam wilayah Indramayu yang dikeluarkan oleh Kementrian Pertanian yang menyebutkan tanggal 18 Juni merupakan waktu awal penanaman tanaman padi (vegetatif).

Lingkaran merah pada Tabel 5 menunjukkan bahwa pada akuisisi citra 5 Agustus 2014 fase yang sedang berlangsung adalah fase vegetatif akhir (tillering menuju stem elongation). Hal tersebut didukung oleh Gambar 13 yang menunjukkan kenaikkan luas lahan sawah yang mengalami tillering (vegetatif akhir) dari 18 Juni 2014 ke 5 Agustus 2014. Fase selanjutnya berdasarkan Tabel 5, pada akuisisi citra Rsat-2 22 September 2014 dan 16 Oktober 2015, tanaman padi mengalami fase panen. Kelas yang menunjukkan fase panen diwakili oleh kelas pasca panen dalam hasil klasifikasi H/A/ $\alpha$ (entropi/anisotropi/alfa). Hal tersebut didukung oleh Gambar 13, dapat dilihat pada 22 September 2014 luas lahan sawah fase pasca panen mengalami kenaikan dari akuisisi citra sebelumnya, begitupun dengan 16 Oktober 2014 yang mengalami kenaikan luas lahan sawah pada fase pasca panen. Jika digunakan skenario lain yang tidak mengacu pada kalender tanam wilayah Indramayu (fase awal bukan vegetatif) dengan alasan heterogennya penanaman tanaman padi maka hasilnya ada beberapa fase yang sesuai dan ada beberapa fase yang tidak sesuai antara luas lahan grafik dan tabel prediksi fase pertumbuhan tanaman padi pada setiap akuisisi seperti pada Gambar 13 dan Tabel 5. Hal ini juga 
akibat dari laut yang ikut terklasifikasi fase germination atau fase seeding sehingga berpengaruh pada luas lahan sawah.

Pada peta klasifikasi fase pertumbuhan tanaman padi di semua akuisisi citra dapat dilihat warna yang paling dominan ditunjukkan oleh warna biru pada peta yaitu pada tanggal 22 September 2014 yang memiliki fase germination (perkecambahan benih)/laut dengan luas lahan $2.368 .242 \mathrm{~m}^{2}$ artinya pada 22 September 2014 banyak petani yang memulai waktu penanaman. Hal ini mendukung hasil dari $\mathrm{H}-\alpha$ classification plane yang menunjukkan hamburan paling dominan berada pada Z9 (fase germination/laut).

\section{KESIMPULAN}

Berdasarkan penelitian yang telah dilakukan, dapat disimpulkan beberapa hal mengenai pemantauan klasifikasi fase pertumbuhan tanaman padi sebagai berikut:

Metode Cloude Pottier yang digunakan dalam dekomposisi polarimetrik dan klasifikasi menghasilkan beberapa parameter diantaranya parameter entropi $(H)$, anisotropi $(A)$, dan alfa $(\alpha)$ yang dapat menunjukkan keragaman umur/fase pertumbuhan tanaman padi sejak 18 Juni 2014 sampai 16 Oktober 2014 berdasarkan rentang kelas masing-masing parameter dimana nilai entropi terendah sebesar 0,00301397 (5 Agustus 2014) dan tertinggi sebesar 0,8955 (18 Juni 2014) serta metode Cloude Pottier ini dapat digunakan untuk klasifikasi fase pertumbuhan tanaman padi.

Klasifikasi dengan menggunakan metode $\mathrm{H} / \mathrm{A} / \alpha$ (entropi/anisotropi/alfa) menunjukkan adanya keragaman fase pada setiap akuisisi citra RSAT-2 dimana setelah dilakukan penyesuaian dengan bidang $\mathrm{H}-\alpha$ classification plane diketahui bahwa keempat akuisisi citra cenderung memiliki nilai hamburan paling dominan pada zona 9 (fase germination/perkecambahan benih atau fase seeding/pertunasan) yang menunjukan mekanisme hamburannya surface scattering. Hal ini didukung oleh luas lahan fase pertumbuhan padi tertinggi dari semua akuisisi citra yaitu fase germination/laut sebesar 2.368.242 $\mathrm{m}^{2}$ (22 September 2014). Metode Cloude Pottier dapat digunakan untuk mengklasifikasi fase pertumbuhan tanaman padi dengan tingkat akurasi sebesar $85 \%$.

\section{DAFTAR PUSTAKA}

[1] Prabowo, D. S., (2014). "Pengelompokan komoditi bahan pangan pokok dengan Metode Analytical Hierarchy Process". Pusat Kebijakan Perdagangan Dalam Negeri, BP2KP, Kementerian Perdagangan - RI.

[2] Agus, B. S., (2006). "Pengembangan Agribisnis Komoditi Beras Melalui Model Klaster Bisnis", Jakarta: Infokop. No 35 th XXVI.

[3] FAO, (2012). "FAO Statistical Yearbook 2012" FAO: Rome, Italy, 2012; pp. 214-280. Tersedia online http://www.fao.org/docrep/015/i2490e/i2490e03d.pdf. Diakses pada 2 November 2014.

[4] Mosleh, M.K. Hassan, Q.K. Chowdhury, E.H., (2015). "Application of Remote Sensors in Mapping Rice Area and Forecasting Its Production: A Review", MDPI Journal doi:10.3390/s150100769.

[5] Badan Pusat Statistik, (2014). "Produksi Padi Menurut Provinsi (ton), 1993-2015". Diakses pada tanggal 31 Maret 2019.

[6] Purevdorj, M dan Kubo, M., (2005). "The Future of Rice Production, Consumption and Seaborne Trade: Synthetic Prediction Method", J. Food Distrib. Res. 2005, 36, 250-259.

[7] Survei Sosial Ekonomi Nasional, (2009 - 2013). "Tabel Konsumsi Rata - rata per Kapita Setahun Beberapa Bahan Makanan di Indonesia". Tersedia online : http://www.pertanian.go.id/Indikator/tabe-15b-konsumsirata.pdf 
[8] Andari, M.T., (2014). "Pemanfaatan Citra RADARSAT-2 Dalam Pemantauan Fase Pertumbuhan Padi”. Institut Pertanian Bogor: Skripsi.

[9] Konishi, T., Suga, Y., Omatu, S., Takeuchi, S., Asonuma, K., (2013). "Rice Crop Growth Monitoring using ENVISAT-1/ASAR AP Mode", Remote Sensing for Environmental Monitoring. 674920(1). DOI: 10.1117/12.737255

[10] Mouche, A. dan Chapron, B., (2015). "Global C-band Envisat, RADARSAT, and Sentinel-1 Measurements in Co-Polarization and Cross Polarization", Journal of Geophysical Research: Ocean, 120 (11),7915-7207.

[11] Cloude, S.R. dan Pottier, E., (1996). "A Riview of Target Decomposition Theorems in Radar Polarimetry", IEEE Trans. Geoscience and Remote Sensing.

[12] Nurtyawan, R. Saepuloh, A. Harto, A.B. Wikantika, K. Kondoh, A., (2017). "Satellite Imagery for Classification of Rice Growth Phase Using Freeman Decomposition in Indramayu, West Java, Indonesia", Hayati Journal of Biosciences Vol. 25 No. 3, DOI:10.4308/hjb.25.3.126.

[13] Putra, P.P. Prasetyo, Y. Haniah., (2015). "Klasifikasi Tutupan Vegetasi Menggunakan Metode Dekomposisi Polarimetrik", Jurnal Universitas Diponegoro.

[14] Ma, Q., (2013), "Application of Radarsat-2 Polarimetric Data for Land Use and Land Cover Classification and Crop Monitoring in Southwestern Ontario". University of Western Ontarion, London: Thesis.

[15] Hajensek, I., (2001). "Inversion of Surface Parameters Using Polarimetric SAR". Dissertation, Ljubljana, Slownien.

[16] Fauzi, N.I., (2016). "Monitoring Fenomena Fase Pertumbuhan Tanaman Padi Menggunakan Citra RADARSAT-2 Multitemporal”. Institut Teknologi Nasional, Skripsi.

[17] Sambodo, K.A., (2011). "Ortho-Rektifikasi Data ALOS PALSAR dengan Menggunakan Data Digital Elevation Model (DEM) dan Teknik Registrasi Citra Berdasarkan Fast Fourier Transform (FFT)", Geomatika SAR Nasional Hal. 17-28.

[18] Ma, Q., (2013). "Application of Radarsat-2 Polarimetric Data for Land Use and Land Cover Classification and Crop Monitoring in Southwestern Ontario". University of Western Ontarion, London: Thesis.

[19] Alberga, V., (2007). "A Study of Land Cover Classification Using Polarimetric SAR Parameters", International Journal of Remote Sensing, Vol.28, No. 17, 3851-3870, DOI: 10.1080/01431160601075541.

[20] Mo, Y.J. Kim, K.Y. Park, H.S. Ko, J.C. Shin, W.C. Nam, J.K. Kim, B.K. Ko, J.K., (2012). "Changes in The Paniclerelated Traits of Different Rice Varieties Under High Temperature Condition". AJCS 6:436-443.

[21] Rahayu, S. Ghulamahdi, M. Suwarno, W.B. Aswidinnoor, H., (2018). "Morfologi Malai Padi (Oryza sativa L.) pada Beragam Aplikasi Pupuk Nitrogen Panicle Morphology of Rice (Oryza sativa L.) under Various Application of Nitrogen Fertilizer", Jurnal Agron. Indonesia, Agustus 2018, 46(2):145-152, DOI: https://dx.doi.org/10.24831/jai.v46i2.18092

[22] Pramono, A. Y., (2012). "Pemantauan Pertumbuhan Padi Menggunakan L-Band SAR Berbasis Teori Dekomposisi: Studi Kasus Subang”. Institut Pertanian Bogor: Skripsi.

[23] Ouarzeddine, M. Aissa, B.A. Souissi, B. Belkhider, M. Boulahbal, S., (2005). "Polarimetric Classification Using The Cloude/Pottier Decomposition", Proc. Of the POlinSAR Workshop. Frascaty, Italy.

[24] Imai, T. Kunii, D. Yonezawa, C., (2015). "Full Polarimetric Observation of Rice Growth by Palsar". Tohoku University.

[25] Toan, L. Ribbes, F. Wang, L.F. Floury, N. Ding, K.H. Kong, J.A. Fujita, M. Kurosu, T., (1997). "Rice Crop Mapping and Monitoring Using ERS-1 Data Based on Experiment and Modelling Result". IEEE Geosci Remote Sens 35:41-56. 